\title{
Kohtaamassa yhteistä maailmaa kolmiulotteisesti
}

\author{
RIIKKA MÄKIKOSKELA
}

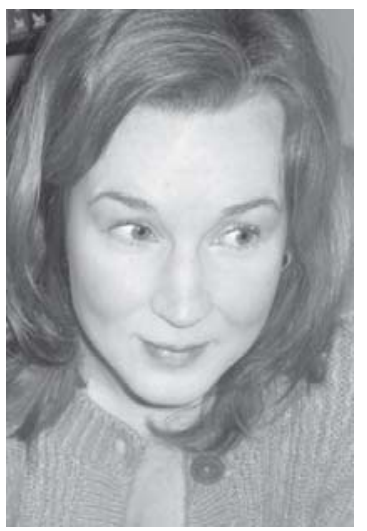

"Tuon tässä artikkelissani esille yhden mahdollisen näkökulman kolmiulotteiseen kuvataiteelliseen työskentelyyn nykyajassa. Samalla pyrin selventämään, miksi koen työskentelyni kuvanveistäjänä tärkeänä ja kuinka kuvataiteellinen työskentely voidaan nähdä perinteisistä taiteilijamyyteistä huolimatta sosiaalisena toimintana: kohtaamisena yhteisessä maailmassamme. Pidän sen perimmäisenä tavoitteena mahdollisuutta mielekkääseen elämään omaksumalla toimiva olemisen tapa ja joustava maailmankuva. Näin se voidaan kokea tuen antamisena yksilön ja yhteisön yhteiselle elämälle", kertoo kirjoittaja Riikka Mäkikoskela.
$T_{\text {e }}$ ekstini taustalla on oletus, jonka mukaan ihminen pyrkii ymmärtämään maailmaa, etsii syitä ja selityksiä toiminnalleen. Hän rakentaa jatkuvasti kuvaansa maailmasta ja sen ilmiöistä tulkiten uutta sekä osallistuen yhteisön toimintaan. Kohtaamalla itsensä, jonkun toisen tai vaikka syntymässä olevan veistoksen tulee usein kokeneeksi ja ajattelleeksi monenlaista. Tällaisessa vuorovaikutuksellisessa toiminnassa tapahtuvat yleensä myös muutokset, joita kutsutaan oppimiseksi.

\section{Toimijana yhteisessä elämismaailmassa}

Omassa kokemuksessani kuvat eivät synny pelkästään ajattelemalla ja visioimalla vaan toimimalla ja tekemällä; en ajattele kuvia valmiiksi päässä, mielessä tai ajatuksissa, vaan työstän niitä mahdollisimman kokonaisvaltaisesti koko kehollani. Koen, ettei kuvataiteellinen työskentelyni onnistu ilman fyysisyyttä, kehollista suhdetta maailmaan. Useat fenomenologit (esim. Parviainen 2000, 148-149; Varto 1990; Merleau-Ponty 2006, 17-20) pitävät ruumista eli raatoa aina ulkopuolisena ja objektiivisena. Se on luonnontieteiden orgaaninen esine, ainoastaan havaittu. Kehon he sen sijaan ymmärtävät elävänä, aistivana havaitsijana ja toi- mijana: se on annettu minulle havainnossa kehonani.

Jaana Parviaisen (2006, 70) mukaan keho on se osa meitä, josta voimme olla tietoisia. Tietoisuutta on siis mahdollista kokea myös mielen ulkopuolella. Liikkumalla ja toimimalla - käyttämällä kehoamme - meillä on mahdollisuus laajentaa kehon aluetta ruumiissamme. Kehona me havaitsemme, muistamme, toimimme taitavasti ja kykenemme muodostamaan tietoa toiminnastamme. Kätemme voivat ajatella, selkämme tunnistaa ja jalkamme tietää. Ihmisenä oleminen on jatkuva prosessi sekä elävänä että ajattelevana kehona (Merleau-Ponty 1962, 82).

Aistinen muodostaa ihmisen ainoan konkreettisen yhteyden ulkoiseen todellisuuteen. Tarkkaan ottaen muuta mahdollisuutta ei taiteilijallakaan ole. Työskennellessään kuvataiteilija on väistämättä myös fyysisessä suhteessa ympäristöönsä, ja siksi kuvia tehdessä suhde maailmaan ${ }^{1}$ on moniaistinen. Fyysisenä toimijana koen olevani osa yhteistä maailmaamme, en ainoastaan sivullinen tarkkailija, kärpänen katossa, kuten Jouko Pullinen (2003, 21) asian muotoilee. Maurice Merleau-Ponty korostaa ihmisen yhteyttä maailmaan aikaan ja paikkaan sidottuna, ei-käsitteellisenä ja vastavuoroisena suhteena. Näin ihminen ei elä koskaan maailmasta eristettynä tietoisuutena, vaan hän kuuluu 
alusta alkaen yhteiseen elämismaailmaamme ${ }^{2}$. (Nordin 1999, 428-429.) Toiminnallisessa kuvataiteellisessa työskentelyssäni voin antaa tilaa havainnoille ja kokemuksille. Pyrin siis suorastaan rakentamaan maailmasuhdetta, joka avaa maailmaa aistisena.

\section{Kuvataiteesta}

Paul Cézannen kerrotaan sanoneen, että kuvataide on henkilökohtaista havainnointia (MerleauPonty 1993, 37). Niin minäkin ajattelen. Taiteessa, joka on pitkälti avoin käsite ${ }^{3}$, koetaan, ajatellaan, nähdään ja kokeillaan. Mika Hannula $(1998,86)$ esittää taiteen merkitykseksi yhtä mahdollisuutta, tai sen yritystä, tulla toimeen todellisuuden kanssa. Minun on vaikea ajatella abstraktisti ainoastaan verbaalisten käsitteiden tasolla. Pohdintaani helpottaa huomattavasti, kun saan aistini mukaan. Esimerkiksi sanan kirjoittaminen paperille katsottavaksi tai muodon tekeminen materiaan kosketeltavaksi toimivat konkreettisina kosketuspintoina asioihin ja ilmiöihin.

Arthur D. Eflandia, Kerry Freedmania ja Patricia Stuhria $(1998,86)$ mukaillen taiteen tarkoitus on koko kulttuurihistorian ajan ollut todellisuuden rakentamisen tehtävä, eikä postmoderni tila ole muuttanut tätä tarkoitusta. Nykytodellisuutemme on mitä suurimmassa määrin sosiaalisesti rakentunutta ${ }^{4}$. Taiteet sisältävät myös sosiaalisen todellisuuden representaatioita ja sosiaalista todellisuutta voidaan tuottaa kuvallisissa käytännöissäkin. Taiteesta saatetaan sanoa, että se on itsetarkoituksellista, taidetta taiteen vuoksi. Ikään kuin sillä ei olisi itsensä ulkopuolista merkitystä. Merleau-Pontyn (2006, 24-25) mukaan taiteella on hyvin perustavanlaatuinen tarkoitus: havaituksi tuleminen.

Sen lisäksi että kuvataideteokset vaativat usein jonkinlaisen fyysisen perustan olemassaololleen, ne ovat riippuvaisia myös ihmisen havaitsemisesta ja ymmärtämisestä. Elämismaailma muotoutuu ihmisen kokemusten kokonaisuudesta: miten asiat sijoittuvat hänen näkökulmastaan ja millaisina ne hänelle näyttäytyvät. Meille on jo tietyt asiat annettuina ${ }^{5}$ maailmassa olossamme, joten emme koskaan aloita esimerkiksi pohdintaamme tyhjästä. Katsomme ja koemme asioita aina tietystä omasta - näkökulmastamme ja meillä on väistämättä kokemuksia ja kulttuurisiakin käsityksiä jo ennen tiettyä katsomis- tai kokemistapahtumaa. (Vuorinen 1993, 333-337.) Martin Heideggerille
(1995, 44-45) taide oli tapa tulla tietoiseksi ihmisen mahdollisuuksista. Taide siis avaa tai perustaa maailman, jonka kokonaisuudessa asiat saavat merkityksen eli asettuvat tiettyihin suhteisiin.

\section{Kolmiulotteisesta kuvataiteellisesta työskentelystäni}

Kuvanveisto näyttäytyy hankalana käsitteenä nykytaiteen kentässä, koska kolmiulotteinen työskentely on laajentunut huimasti perinteisen veistämisen ja muovailemisen ulkopuolelle. Toiminnan kaikki mahdollisuudet, esimerkiksi rakentaminen, punominen tai rikkominen, ovat yhtä olennaisia keinoja päästä kohti haluttua järjestystä kolmiulotteisessa kuvataiteellisessa työskentelyssä. Rakentamisesta ollaan siirrytty myös tilan muovaamiseen. Osa nykyveistoksista muotoutuu kokemisen ja ajattelemisen myötä käsitetaiteelle tyypilliseen tapaan. Myös tila ja ihmisen suhde tilaan ovat keskeisesti läsnä. (Sakari 2000, 228-229.) Jyrki Siukosen $(2002,11)$ sanoin nykykuvataiteessa ei oikeastaan ole enää kysymys siitä, miten taideteos rakennetaan vaan siitä mistä ja miten siihen muodostetaan merkityksiä. Tällaiset kuvataidekäytännöt edellyttävät niin fyysistä kuin abstraktimpaakin suhdetta todellisuuteen.

Käytän kuvanveistäjän, veistoksen ja kuvanveiston käsitteitä siinä merkityksessä, että ne kattavat kolmiulotteisen kuvataiteellisen työskentelyn. Jotkut saattavat kutsua teoksiani tilataiteeksi tai installaatioiksi. Toiset ovat sitä mieltä, että ne ovat veistosinstallaatioita. ${ }^{6}$ Itse käytän käsitettä veistos, vaikka harvoin työskentelen veistämällä. Tämä perinteinen käsite kertoo mielestäni edelleen olennaisen asian: kysessä on kolmiulotteinen taideteos tilassa.

Tekijän näkökulmasta kuvanveistotaide näyttäytyy visuaalisen luonteensa lisäksi fyysisenä, käsinkosketeltavana, tuntoaistiin perustuvana. Sen lähtökohdathan ovat kolmiulotteinen tila, valo, materiaali ja painovoima. (Morris 1993, 3-4.) Kolmiulotteiseen kuvataiteelliseen työskentelyyn kuuluu voimakkaasti taitelijan keho, joka liikkuu myös syvyyssuuntaisesti kolmiulotteisessa tilassa. Se harvoin pysähtyy samalla tavalla laajaan, yksipuoliseen pintaan kuten kaksiulotteisessa kuvataiteellisessa työskentelyssä. Kun kohtaamme veistoksen tilassa, havainnoimme sitä kinesteettisesti, haptisesti ja refleksiivisesti liikkumalla sen ympäri kyseisessä tilassa (Morris 1993, 89). Saatamme kohdata se kuin toisen olennon, ihmisen- 
kaltaisena. Juuri tämä kohtaaminen on minulle kuvanveistäjänä tärkeää.

Miellän kuvataiteellisen työskentelyni ensisijaisesti toiminnaksi, koska työskennellessäni toteutan ajatteluprosessejani tekemällä. Jotta teoksen aineellinen perusta muotoutuu, minun on työskenneltävä fyysisesti. Silti koen liittyväni myös käsitetaiteen perintöön. Kun 1960-luvun analyyttiset käsitetaiteilijat pyrkivät eroon taideteoksen aineellisuudesta, koska taiteesta piti heidän mukaansa tehdä kysymisen kohde, kielen ja kielellisen ajattelun asia, filosofinen tutkimusaihe, niin uuskäsitetaiteilijat ovat viime vuosikymmeninä korostaneet, ettei ainoastaan kielellinen, käsitteellinen tai abstrakti ajattelu riitä kattamaan eletyn maailmamme merkityksiä. (Iitiä 2003, 126-127.) Uuskäsitetaide on ulottanut pohdinnat inhimilliseen elämään ja ympäröivään maailmaan sekä kielen ja maailman että todellisuuden ja representaatioiden välisille monille tasoille. Viime vuosikymmeninä veistokset ovat ottaneet yhä enemmän huomioon ympäristöään ja niissä on nähtävissä uudenlaista tilallista pyrkimystä: ne suuntaavat katsetta teoksen lisäksi sen fyysiseen, sosiaaliseen, poliittiseen ja filosofiseen ympäristöön. (Sakari 2000, 66; Morris 1993, 26.) Maaretta Jaukkuri (1998, 33-35) kirjoittaa tietoisesti perinteeseen kytkeytyneestä nykykuvataiteesta, jonka alueella pyritään antamaan muoto välittömälle kokemusmaailmalle suhteessa oleviin merkkeihin, merkityksiin ja kuvamalleihin. Tällaisessa kehyksessä kuvataiteellinen työskentelyni voidaan nähdä avoimina tulkintakenttinä, liikkeenä kokemuksellisuuden ja käsitteellisyyden välillä.

Teokset eivät ole täysin valmiina mielessäni ennen työskentelytapahtumaa. En edes pyri siihen. Minusta mielenkiintoisempaa on, miten kuva syntyy ja muokkautuu tekovaiheessa, joka on useinmiten kysyvä tapahtuma. Työssäni tärkeimmäksi koenkin ihmettelyn ja epäilyn; jäsennän maailmaa kyseenalaistamalla. Tekemisentapahtuma ei ole minulle vain jotain, joka jää veistoksen taakse, vaan työskentelyn ja mahdollisen teoksen pääsisältö. Taiteellisesti työskennellessäni olen huomannut, että kolmiulotteisuuden myötä kehollisuuden, liikkeen ja välittömän kokemuksellisuuden mahdollisuudet korostuvat, kun minulla on suora ja omakohtainen kosketus tilalliseen todellisuuteen. Koska tilan, paikan ja syvyyden kokemukset ovat ihmiselle mahdollisia ainoastaan liikkuvan kehon havainnossa (Parviainen 2006, 27) kolmiulotteinen taideteos kohdataan kehollisena, tilallisena suhteena. Kuvantekijänä, ihmisenä, kehona, muotona ja tilana kohtaan myös fyysisesti toiminnallisen ajattelun myötä kolmiulotteisessa kuvataiteellisessa työskentelyssä hahmottuvan tilan ja muodon. Koen, että tällöin selkeät rajat mielen ja ruumiin sekä minän ja maailman väliltä häipyvät: tunnen olemassaoloni kolmiulotteisena tilana, kehona. Kun keho on annettu minulle havainnossa kehonani, voin kokea ja ymmärtää tilallisuutta sekä minussa että ympäristössäni. Parviainen $(2006,205)$ korostaa vielä, että tilan käyttäminen edellyttää kinestesiaa ${ }^{8}$, sillä liikkumalla kykenemme hahmottamaan etäisyyksiä, muotoja, massoja, kokoja ja syvyyksiä, jotka ovat fyysisiä ominaisuuksia.

Kuvataiteellisella työskentelyllä, joka on minulle niin sanallista, kehollista kuin visuaalistakin, voidaan herättää kysymyksiä merkityksistä, jotka ovat jo aisteille läsnä ennen kuin niitä voidaan tietoisesti mielessä käsitteellisesti ajatella tai niistä sanallisesti puhua. Taide voi herkistää aistejamme ja pitää yllä ihmisen valppautta todellisuuden kohtaamisessa, joka ei ole vielä jäsentynyt esimerkiksi verbaalisesti. Kuvataiteellisessa työskentelyssä voin mennä vieraille alueille kokeilemaan ja sieltä käsin - ikään kuin paikan päällä - voin aloittaa tuntemattoman jäsentämisen ymmärrettävämmäksi.

Luova työni on siinä mielessä heittäytymistä tuntemattomaan, ettei asioille ole aina ennalta nimeä eikä minulla kokonaisvaltaisempaa käsitystä niistä. En siis aina tiedä mitä minulla on vastassa. Kuten jo aiemmin kirjoitin, yleensä etsintä aloittaa luovan prosessin. Roman Ingardenin (2000, 10 $11,14)$ sanoin siinä muoto löytää ontologisen perustansa ja tuo konkreettisesti itsensä ilmi. Koska kehollisen taiteilijan työprosessi alkaa jo vaiheessa, jossa käsitteet eivät vielä nouse, hänellä ei voi olla työhön ryhtyessään vielä selvää, käsitteellistettyä tarkoitusta. Esitietoinen aines säilyy mukana, koska teko toteutetaan aistisena, kehollisena toimintana. Usein intentio löytyy vasta työskentelyn aikana. Taiteessa ei ole kyse jo olemassa olevan idean todentamisesta, eikä subjektin hallitsemasta esittämisestä (Luoto 2000, 112; MerleauPonty 1993, 39-40). Tarja Pitkänen-Walter (2001, 134) tähdentää, ettei haltuunottamattomuus kuitenkaan tarkoita suunnattomuutta tai pyrkimyksettömyyttä. Suunnan ja pyrkimyksen ohella maailma tapahtuu myös tahtoani vastaan, en kykene hallitsemaan sitä. Tämän vuoksi työskentely tuottaa usein yllätyksiä. 


\section{Kohtaamassa}

Kolmiulotteista kuvataiteellisen työskentelyn tapahtumaa ohjaava kehollinen toiminta on olennaista, jotta teoksen aineellinen perusta muotoutuu. Tätä muokkaamista tekevät ja ohjailevat sekä taiteilija että teos, joka alkaa hahmottua tuossa kokemuksessa: kohtamisessa. Taideteoksella on siis kehittyvä rakenne, joka selkiytyy taiteilijalle työn jäsentymisen kuluessa. Juuri teoksen näkeminen, tunteminen ja kokeminen mahdollistavat aineellisen perustan muokkaamisen. Taiteilija on oman kehittymässä olevan työnsä tarkastelija, mutta kyseessä ei ole täydellisen passiivinen vastaanottaminen vaan aktiivinen toiminta. (Ingarden 2000, 7-9.) Vaikka kuvataiteilijana koen olevani aina teosteni ensimmäinen katsoja ja kokija, en halua jättäytyä vain kuvieni eteen. Sen sijaan haluan kohdata ne dialogisessa työskentelytapahtumassa, joka muokkaa meitä molempia.

Merleau-Ponty (1962, 322; 1993, 44) kirjoittaa, että minän, minuuden ja olemassaolon juuret ovat kehossa ja sen suhteessa ympäristöönsä. Emme koskaan pääse pois elämästämme, eikä aistiva ja aistittu keho voi milloinkaan olla itseriittoinen. Jos olen olemassa, olen aina yhteisessä maailmassamme, ja maailma on aina myös minussa. Maailmassa oleminen - dialogi aistivan ja aistitun välillä muotoutuu näin jakamiseksi, molemminpuoliseen säätelyyn sekä vaihtoon perustuvaksi suhteeksi. Tällöin myös ilmaisu, esimerkiksi kuvataiteellinen työskentely, nähdään luonteeltaan kaksipuolisena ja vastavuoroisena.

Taideteos syntyy asteittain monivaiheisessa prosessissa, ja näihin vaiheisiin liittyy jatkuva yhteys toimivan, kokevan taiteilijan ja syntymässä olevan teoksen välillä. Myös tällainen vuorovaikutus on aktiivista ja elävää molemmin puolin. (Ingarden 2000, 18.) Tony Craggin (1999b, 109, 112) mukaan veistokset syntyvät nimenomaan materiaalin ja taiteilijan välisestä dialogista ${ }^{9}$, eikä aina voida sanoa kumpi johtaa, tekijä vai teos. Jatkuva ja mykkä vuorovaikutus taiteilijan ja aineen välillä voi muistuttaa intiimiä, keskustelevaa suhdetta. Tämän keskustelun perusteella taiteilija tekee päätöksiä, joiden mukaan hän etenee työskentelyssään. Teos on tämän äänettömän dialogin näkyvä ilmentymä, aivan kuten keskustelu on kahden henkilön välisen verbaalin vuoropuhelun havaittava ilmenemismuoto. (Pasanen 2005, 29.)

Teos ei synny vain läsnäolemalla, vaan se vaatii taiteilijaa myös ottamaan etäisyyttä itsestään, sillä teos on tekijänsä ja ympäristönsä suhde. Toiset voidaan nähdä jälkinä, joita seuraamalla saatamme päästä ulos omasta todellisuudestamme yhteiseen maailmaan. Toinen voi siis osoittaa meille omamme sijasta yhteisen maailman. (Varto 1994, 59.) Hannula, Suoranta ja Vadén $(2003,13)$ esittävät taiteellisen työskentelyn olevan vuorovaikutusta ja yhdessä oloa, vaikka ketään muuta ei olisikaan paikalla. Sosiaalinen välittyminen voi siis tapahtua kulttuuristen tuotteidenkin kautta, aivan kuten Pullinen (2003) tutkimuksessaan osoittaa. Artefakteihin tallentuu sosiaalisesti jaettuja symbolisysteemejä, jotka pitävät sisällään kulttuurista ymmärrystä. Nekin ovat väistämättä sidottuja siihen kulttuuriseen ja sosiaaliseen tilanteeseen, jossa ne ovat syntyneet. (Tynjälä 1999, 148-151.)

Kuvataiteellinen työskentelyni on parhaimmillaan äänetöntä vuoropuhelua minun ja tulevan teokseni välillä: kyseessä on kahden subjektin suhde. Pauline von Bonsdorff $(2000,190)$ kuitenkin huomauttaa esteettisen objektin muotoutuvan subjektiksi vain elävässä kokemuksessa. Teokseni ja itseni välisessä dialogissa ajattelen materian avustuksella, jolloin voin tarkastella asioita itseni ulkopuolella yhteisessä elämismaailmassamme. Kun mukana on sekä maailma että tekijä, kyse on maailmasuhteen uudistamisesta. Silloin yhdistyvät myös kehollisuuteen kuuluvat aineellisuus ja käsitteellisyys - näkyvä ja näkymätön.

Merleau-Pontyn (2006, 39) mukaan vain konkreettinen syvyys voi olla osallistumista yhteiseen maailmaamme, tilalliseen olevaan. Tilaan astuminen ja siihen osallistuminen vaativat useiden aistien läsnäoloa. Tämän vuoksi tilallisuus ei voi koskaan paljastua liikkumattomalle keholle. Ilmeneminen on jatkuvaa liikkeellä olemista ja se vaatii avoimuuteen asettumista. Maailma kokonaisuudessaan ei ole ymmärrettävissä ilman kehollista havaitsemista tai kehollinen subjekti ilman toista. Toisen kohtaamiseen kuuluva epäidenttisyys, ristiriitaisuus, monimerkityksellisyys ja epävarmuus on vain hyväksyttävä, sillä yhteinen maailmamme ei ole selkeän musta-valkoinen.

\section{Oppimassa}

Elämässämme käänteet ovat usein nopeita sekä ennustamattomia ja ristiriitaisia. Uusissa tilanteissa joudumme aina uudestaan pohtimaan suhdettamme itseemme sekä toisiin ${ }^{10}$. Ympäröivän maailman jäsentyminen edellyttää kerta toisensa jälkeen havaitsijan liikkumista ja aktiivista osallistumista 
ympäristönsä muokkaamiseen (Lyytinen, Eklund \& Laakso 2000, 46). Aivan kuten Merleau-Ponty (2006, 24, 48) kirjoittaa: maailma ei ole edessämme, se on ympärillämme.

Minulle taiteen ydin on se muutos, jonka se tekijässään, kokijassaan tai katsojassaan aiheuttaa. Haluan korostaa liikettä, sillä myös teoksista löytyvät ja niihin sijoitettavat merkitykset ovat harvoin yksiselitteisiä ja jatkuvassa muutoksessa. Ajattelun sekä toiminnan muutoksia voidaan kutsua myös oppimiseksi. Näin tehdään konstruktiivisen oppimisnäkemyksen piirissä, jossa oppiminen nähdään uutta luovana toimintana. (Tynjälä 1999, 12, 21-22, 129-130.) Nykyään oppimisen käsite ymmärretään yleisestikin hyvin laajana. Se voidaan nähdä perinteiseen tapaan tiedon määrän lisääntymisenä ja muistamisena tai faktojen, taitojen ja työmenetelmien hankkimisena tai soveltamisena mutta myös merkitysten abstrahointina, tulkintaprosesseina ja ymmärtämisenä sekä ajattelun, toiminnan ja ihmisen itsensä muuttumisena (Uusikylä \& Atjonen 2000, 124). Vaikka uutta luovaa, kriittistä, produktiivista ja kokeilevaa oppimista on aina tapahtunut tieteen ja taiteen piirissä, sitä ei ole kutsuttu oppimistoiminnaksi vaan uuden tiedon tai esteettisen elämyksen luomiseksi (Tynjälä 1999, 129-130).

Jotta voisimme oppia uutta, meidän on tiedostettava toimintaamme ja ajatteluamme. Oman toiminnan tietoisen tarkkailun avulla voimme tulla tietoiseksi havaintojamme ohjaavista olettamuksista ja uskomuksista, ja tämän tiedostamisen kautta kykenemme tarvittaessa muuttamaan näitä oletuksia. Tämä on Päivi Tynjälän $(1999,97)$ mukaan oppimisen kannalta kaikkein keskeisintä. Kuvantekemisen myötä tulen tietoisemmaksi omista käsityksistäni kokonaisvaltaisemmin, kun tunnistan ja erittelen myös käsitteellistämätöntä ajatteluani. Kokonaisuudessaan ajatteluni toteutuu siis konkreettisesti tekemällä. Voisin myös sanoa, että opin ja ymmärrän asioita tekemällä.

Toiminnassaan ihminen peilaa usein itseään kokemaansa ilmiöön ja pyrkii näin selkeyttämään vastavuoroista suhdettaan maailmaan. Useiden tutkimusten valossa minäreferenssi, asioiden suhteuttaminen omaan itseen, on tehokas tapa käynnistää oppimiseen liittyviä prosesseja (Rauste-von Wright ym. 2003, 58). Tapio Vaherva (2002, 97) käyttää kokemuksellisesta oppimisesta käsitettä informaali toimintaoppiminen, jossa oppiminen tapahtuu toiminnan kautta: työtä tekemällä ja sitä tutkimalla. Kokemusperäinen oppiminen kuvataiteelli- sessa työskentelyssä edellyttää välttämättä kykyä analysoida ja tiedostaa omaa visuaalista, kehollista ja verbaalia kieltä sekä oppimista, koska tietämistä ja taitamista syntyy koskien kuvallista ilmaisua, omaa itseä ja oppimisen prosesseja. Oppimisen tulokset koetaan yleensä mielekkäiksi, jos niitä voidaan soveltaa saman tien omaan toimintaan. Kun oppija kykenee tarkastelemaan omaa toimintaa ja sen tuloksia kriittisesti, hän voi muokata aiempia käsityksiään ja tietojaan. Tämä prosessi on Rauste-von Wrightin ym. $(2003,156)$ mukaan oppimisen ydin, ja siksi he luonnehtivat oppimista toiminnan sivutuotteeksi.

Olenkin huomannut löytäväni tietoa ja ymmärrystä taiteellisesti työskennellessäni. Silloin kuvan tekeminen ei ole ainoastaan nautittavaa puuhastelua, vaan sillä voidaan myös pyrkiä johonkin. Taiteellinen työskentelytapahtuma voi olla merkityssisältöjen abstrahointia, tulkintaa ja sisäistämistä, joka muuttaa ajattelua ja toimintaa eli laajentaa sekä kasvattaa ymmärrystämme. Työskentelyni lähtökohta ei kuitenkaan ensisijaisesti ole tehdä, jotta saisin lisää tietoa tai että ymmärtäisin enemmän. Useinmiten työskentelen, koska se tuntuu mielekkäältä ja kiinnostavalta tavalta olla, toimia ja pohtia. Mutta miksi koen näin? Koska kuvataiteellinen työskentely mahdollistaa kehollisen maailmassa olemisen, johon kuuluvat myös aistiset, esteettiset kokemukset ${ }^{11}$. Analyyttisyyteen pyrkivän mielentietoisuuteen verrattuna tällaiset aistiset kokemukset ovat usein epämääräisiä, epätarkkoja ja subjektiivisia, mutta samalla ne paljastavat maailmasta ja tajunnasta sellaisen ulottuvuuden, jota pelkkä analyyttinen, kielellinen ajattelu tai kokeellinen mittaus eivät paljasta - nimittäin kokonaisuuden.

Kun maailmasuhteeni muotoutuu kokonaisemmaksi ${ }^{12}$, saan tietoa maailmasta laaja-alaisesti. Tietäminen - niin kuin kehollinen maailmassa oleminenkin - on perusolemukseltaan vuorovaikutteista. Käsitän tietämisen ja myös oppimisen kulttuurisidonnaisena, kontekstuaalisena ja situaationaalisena tapahtumana. Tietäminen on minulle aktiivisuutta, joka syntyy taitavan toiminnan myötä. Se voi ilmetä ja kulkea sanallisessa tai sanattomassa muodossa. Tietämisen sanallistaminen ei ole aina tarpeen, sillä keho on reflektiivinen, muistava ja ajatteleva. Ainoastaan kehollinen toiminta voi herkistää keholliselle tiedolle. Siihen tarvitaan kinestesiaa eli kokemusta oman kehon liikkeistä, jotka avaavat tärkeän tiedollisen, sosiaalisen ja emotionaalisen yhteyden maailmaan (Parviainen 
2006, 9). Kehoni kartan avulla voin ymmärtää kokemukseni synnyn, merkityksen ja laadun kehossani. Merkitykset syntyvät, kun kehoni sijoittaa itsensä maailmaan. Kolmiulotteinen kuvataiteellinen työskentelyni tuo esiin kehossani olevat mahdollisuudet, jotka jäisivät paljastumatta pelkän verbaalisen, visuaalisen tai kuvitteellisen kautta.

\section{Lopuksi}

Kehollisen toimijan taiteellinen työskentely muotoutuu laaja-alaiseksi maailmasuhteeksi, jonka luonne on kaksipuolinen ja vastavuoroinen. Kun minulla on myös aistinen yhteys syntymässä olevaan teokseeni, se voidaan ymmärtää dialogiseksi suhteeksi subjektiin. Aina en kykene sanomaan johdako minä vai teos tapahtumaa. Dialogia ei ole tarkoituskaan hallita. Se on vastavuoroinen: me molemmat - minä ja maailma - annamme ja saamme.

Kehoni liike saa merkityksensä auttaessaan minua hahmottamaan sanatonta kokemusta maailmasta. Asiat saattavat olla jo aisteilleni läsnä, ennen kuin voin niitä sanallisesti pohtia. Työskennellessäni pyrin avoimuuteen sekä herkistyneeseen kehontietoisuuteen. Näin voin ajatella ja pohtia myös ilman sanoja, eli toimintaa ohjaava ajatteleminen on jotain muutakin kuin pään sisäistä puhetta. Intensiivisessä taiteellisessa työskentelytapahtumassa yhteys ajattelun ja tekemisen kesken on saumaton. (Pullinen 2003, 25-26.) Vaikka rationaalinen ajattelu ei ole taiteellisen toiminnan pääosassa, Ingardenin $(2000,24)$ mukaan tajunnalliset intentionaaliset kokemukset muodostavat siitä perustavan osan. Työskentelytaitojen kasvaessa kehontietoisuuden ei tarvitse keskittyä ainoastaan toiminnan ohjaamiseen, vaan se voi etääntyä fyysisistä liikkeistä ja askarrella myös muiden asioiden parissa. Kun suurin osa teknisen suorituksen ulkoisesta muodosta siirtyy tietoisuuden ulkopuolelle, kehon sisäinen kokemus ja sen tutkiminen voivat siirtyä tietoisuuden keskiöön (Klemola 2005, 120). Toisaalta kun koko tietoisuutta ei tarvitse keskittää fyysisen toiminnan ylläpitämiseen, se voi kohdistua myös teoksesta nouseviin asioihin. Silloin koen kuvantekemisen johdattavan ajatteluani. Kyseessä olevasta työskentelyhetkestä tulee voimakkaasti tilallinen ja aineellinen. Olen sekä itsessäni että itseni ulkopuolella etsimässä sanatonta ja keskeneräistä, joka avautuu dialogisessa, kuvataiteellisessa työskentelyssä eletylle, koetulle keholle. Silloin kuvataiteellinen työskentelyni on toimintaa aistisen ja käsitteellisen, aineellisen ja kielellisen sekä käytännöllisen ja teoreettisen välimaastoissa.

Kuva tuo esiin näkyvän ja näkymättömän keskinäisen yhteyden. Teokseni ovat henkilökohtaisia tulkintojani niiden tekemisen yhteydessä käsittelemistäni asioista ja ilmiöistä. Ne luovat sekä henkisen että fyysisen jatkumon minun ja maailman välille, katkeamattoman ja vastavuoroisesti aktiivisen yhteyden aistivasta aistittuun ja päinvastoin. Kuvataide tekee maailman näkyväksi mutta mikä tärkeintä - se esittää samalla kysymyksiä näkyvästä, näkymättömästä ja niiden merkitysten synnystä. (Pasanen 2006, 91.) Kuvia tehdessäni koen keskustelevani myös itseni kanssa materian avustuksella, kun voin tarkastella asioita itseni ulkopuolella. Tarkemmin sanoen näen, pystyn koskettelemaan, kokemaan ja kokeilemaan käsittelemiäni asioita teoksessa, jolloin yhteyteni maailmaan täydentyy: se on myös näkyvää ja koettavaa olemassaoloa.

Kuvia tehdessäni erittelen taiteen kautta syntyvää suoraa yhteyttä kokemiseen ja kokemuksen sisällön ymmärtämiseen, järjestän ympärillä olevaa maailmaa ja etsin omaa paikkaani siinä. Kuvataiteellisessa työskentelyssäni minun ei tarvitse ainoastaan kuvitella asioita, vaan voin etsiä havaitsemisen, kokemisen, muistamisen, uskomisen, näkemisen, tietämisen ja arvostamisen sekä niiden kohteiden rajoja konkreettisesti näkyvänä ja koettavana toimintana. Maailma tulee näkyväksi nähtynä mutta myös kehon liikkeiden, toiminnan ja käytännön kautta (Kupiainen 1997, 22). Kun toimin aistisena maailmassa, siihen liittyy myös maailman vastus. Näin maailma osallistuu sen tavan määrittämiseen, jolla ihminen voi toimia ja ajatella. (Varto 1994, 34-35.) Mieli on kuvittelun ja luulon luomus, jonka avulla voimme kävellä jopa seinien läpi. Aistisessa kokemuksessa maailma vastustaa tällaista toimintaa. Kolmiulotteisia kuvia tehdessäni minun ei tarvitse kuvitella asioita oleviksi, todellisiksi.

Taidon karttumisen ja onnistuneen työskentelyn myötä voin tuoda kokemaani ja tuntemaani sisäisestä ulkoiseksi, konkreettiseksi materiaan. Saan etäisyyttä itsestäni ja olen mukana olevan avautumisessa. Koska minä olen maailmassa ja maailma on myös minussa ${ }^{13}$, voidaan sanoa, että keskustelen myös itseni kanssa materian avustuksella. Kuvani luovat niin henkisen kuin fyysisenkin jatkumon minun ja maailman välille. Avatessa- 
ni kehoani maailmalle etäännyn itsestäni. Oma paikkani maailmassa hahmottuu tämän ajattelun ulkoistamisen myötä. Voin myös aina palata näkyvästä ja koettavasta takaisin itseeni.

Kuvallinen työskentely on minulle aistisen olemassaolon tutkimista, kun taiteen keinoin voin tuoda näkyväksi, koettavaksi ja ajateltavaksi myös aikaisemmin kokemaani ja tunnustella, tulkita sekä ymmärtää sitä uudelleen. Saatan näin jo olemassaolevaa eri tavoin ilmeneväksi. Konkreettisina kosketuspintoina ja muotoina on toisinaan helpompi nähdä ja käsittää. Maailman ja käsitteellisen ajattelun välinen yhteys syntyy useinmiten havainnon kautta. Sanallinen käsitteellistäminen ei vaikuta alkuperäiseen kokemukseen, mutta se voi asettaa monimuotoisemmin oivalletun kiinteämmin maailmaan.

Kuvanveistäjänä olen etsimässä ihmiselämän merkityksellisyyttä. Minulle se syntyy siitä, kun voin osallistua yhteiseen maailmaamme minulle luontevalla tavalla, aistisena maailmassa. Koen kuvataiteellisen työskentelyn aktiivisena ja omakohtaisena toimintana, jonka myötä henkilökohtaiset käsitykset ja merkitykset muodostuvat. Se voidaan kuitenkin ymmärtää myös sosiaalisena vuorovaikutuksena, jossa oppiminen tarkoittaa Eteläpeltoa ja Rausku-Puttosta (2002, 203) lainaten niin henkilökohtaisten kuin sosiaalisesti jaettujen merkitysten muodostamista.

Kun ihminen kokee itsensä elävänä ja ajattelevana kehona, oppimiseen liityy tiedon kognitiivisen, rationaalisen ja loogisen puolen lisäksi myös inhimillisesti arvokkaita kokemuksia, kuten elämyksiä, aistimuksia, ja tunteita. Inhimillisen kasvamisen ja oppimisen kautta tulen tietoisemmaksi omasta todellisuussuhteestani ja tämän myötä myös tietoisemmaksi itsestäni. Itseymmärryshän johdattaa meitä yleensä kohti mielekkäämpää elämää. Sitä ei synny ilman toisia ja yhteistä maailmaamme. Kolmiulotteisessa kuvataiteellisessa työskentelyssäni etsin aineellisia tartuntapintoja minun ja maailman välillä. Usein veistos yllyttää minua kysymään vielä lisää pystyttämällä maailman ja asettamalla esiin materian. Työskentelyni antaa tukea minun ja yhteisön yhteiselle elämälle, ja sen myötä ymmärrän yleensä hiukan enemmän siitä, kuka minä olen, mistä olen tullut ja millaisten ilmiöiden keskellä elän.

Marja Sakari $(2000,180)$ näkee kuvataiteen tekemisen näkymättömään ja olemisen mielekkyyteen osoittamisena. Taide voi saada nämä ilmenemään. Nykymaailmassa asiat ovat olemassa - il- menevät oikeasti - meille harvoin. Kuten Parviainen $(2006,162)$ toteaa: näkyvän ja kosketettavissa olevan yhteyden puuttuminen on historiallisesti uusi tilanne. Meidän on suuntauduttava ympäristöömme enenevässä määrin myös sitä ennustellen. Vähitellen aistimme hiljenevät, kun muistelemme, suunnittelemme ja päättelemme verbaalisesti mielessä välittämättä siitä, mitä ne voisivat kertoa. Jos kuitenkin siirtäisimme huomiomme kehontietoisuuden alueelle, palaisimme käsillä olevaan hetkeen ja olisimme läsnä kyseisessä hetkessä. Todellisuuden jäljenteistä muodostunutta maailmaa hallitsemme helpommin, oikea elämä on vääjäämättä hallitsematonta. Kärjistäen voitaisiin sanoa, että käsitteellistyvä maailmamme muuttuu kiihtyvällä vauhdilla istuvan ihmisen kaksiulotteiseksi pinnaksi, illuusioksi, josta puuttuu syvyysulottuvuus. Sitä on helpompi koordinoida, mutta muun muassa se ruokkii olemassaolon tarkoituksettomuuden tunnetta. Pinnaksi muodostuneena oleminen ohenee, koska yhteisessä maailmassa oleminen on tilallista läsnäoloa, kehollista maailmassa oloa. Ainoastaan kolmiulotteinen syvyys voi olla todellista osallistumista yhteiseen maailmaamme, tilalliseen olevaan (Merleau-Ponty 2006, 39).

Tarvitsen kolmiulotteista kuvataiteellista työskentelyäni, koska en osaa järjestellä ja ajatella ainoastaan abstraktisti sanojen avulla mielessä. Jos olemiseni ohentuisi pelkäksi kaksiulotteiseksi illuusioksi, elämäni olisi aikalailla köyhempää. Tämän vuoksi en haluaisi kadottaa omakohtaista ja suoraa kosketusta todelliseen syvyyteen; en tahtoisi korvata todellisuutta sitä esittävillä vastikkeilla. Toisinaan kolmiulotteinen kuvataiteellinen työskentelyni synnyttää uusia kokemuksia itseni ja ympäristöni suhteesta. Nämä uudet kokemukset voivat laajentaa ymmärrystäni. Siksi kuvataide parantaa mahdollisuuksiani ymmärtää kokonaisvaltaisesti havaintoon perustuvaa suhdettamme todellisuuteen, ja sen myötä olen juurevammin osa yhteistä maailmaamme.

Jotta elämäni olisi mielekästä, tarvitsen näkyvän ja kosketeltavan yhteyden materiaan, joka vastavuoroisena antaa minulle tuoreita näkökulmia yhteiseen elämäämme.

\section{Viitteet}

1. Varton $(1994,155)$ mukaan maailma on se kaikki, mitä on. Maailmassa oleminen merkitsee, että olemme aina ensisijaisesti yksi osa sellaista kokonai- 
suutta, jota emme voi koskaan kokonaan tuntea (Varto 1994, 35).

2. Elämismaailma, Edmund Husserlilta peräisin oleva käsite Lebenswelt, on filosofinen nimitys arkielämälle. Se on teoreettisen ajattelun ja hallinnollisten järjestelmien vastakohta. Ajatus elämismaailman ensisijaisuudesta tarkoittaa, että myös teoreettisen ajattelumme pohjana on jokapäiväinen, käytännöllinen suhteemme todellisuuteen. (Hetemäki 1999, 50.) Merleau-Ponty kääntää Lebenswelt -käsitteen ranskaksi monde vécu. Juha Varton (1990, 123-124) mukaan hän korostaa Husserlia johdonmukaisemmin eletyn maailman henkilökohtaisuutta sekä sen kokemuksellista puolta, jolloin kyseessä ei ole enää annettu maailma perinteisessä merkityksessä vaan mukana on myös mahdollisuus siitä, mitä olen ottanut maailmakseni.

3. Morris Weitzille taide on avoin käsite, eli emme tarvitse taiteen olemuksellista määritelmää, jotta voisimme puhua mielekkäästi taiteesta tai pohtia, onko jokin teos taidetta vai ei. Taide on muuttuva ilmiö, koska aina voi syntyä uudenlaisia teoksia, joiden kohdalla joudumme miettimään, venytämmekö taiteen käsitettä kattamaan uudetkin tapaukset. Taiteen käsite ei ole ainutlaatuinen, myös suurin osa empiirisistä käsitteistämme ovat avoimia. (Vuorinen 1993, 350-351.)

4. Esimerkiksi raha, omaisuus, aviolitto, sukupuoliroolit, lainsäädäntö, rasismi sekä humanistiset tieteet ja taiteet.

5. Annettu on olemassa yhtä itsestäänselvästi kuin ihminen itse, eli se ei ole ihmisen itsensä luomaa. Esimerkiksi luonto, kulttuuri ja kieli ovat annettuja. Myös maailma on annettuna meille lukuisilla eri tavoilla. Mikään niistä ei ole koko maailma, vaan yhdessä ne antavat maailman. Tätä kokonaisuutta kutsutaan elämismaailmaksi. (Varto 1994, 32-34.)

6. Ks. esim. www.riikkamakikoskela.fi.

7. Hän viittaa Husserliin todetessaan, että liike on olennaista, jos halutaan kokea ja ymmärtää tilallisuutta. Kosketus- ja näköaistimus tekee ymmärrettäväksi esineen materian ja kinestesia esineen tilallisuuden.

8. Kinestesilla Parviainen (2006, 9, 27) tarkoittaa ihmiskehon toiminnallisuutta ja liikekokemuksia.
Se on kokemusta oman kehomme liikkeistä, siis liikeaistimusta koskevaa tai liikkeen kokemiseen liittyvää.

9. Dialogisen kanssakäymisen idea ei ole opettaa meille, miten asiat ovat, vaan saada meidät tutkimaan itseämme ja tarkkailemaan uskomuksiamme sekä asenteitamme. Tarkoituksena ei siis ole abstraktin tiedon omaksuminen vaan pikemminkin maailmankuvan muutos.

10. Tämä on selitys sille, että tilanteiden ja ajan vaihtuessa on aina tarvetta tehdä uusi kuva jopa täsmälleen jo tehdystä tai samasta aiheesta. Merleau-Ponty (2006, 70-71) kirjoittaa, ettei teos maailmasta voi tulla koskaan valmiiksi, eikä kaikkea taidetta ole vielä toteutettu. Ks. myös Cragg 1999a, 104.

11. Esteettisen ymmärrän aistiseksi, aistihavainnolliseksi tai kaikkiin mahdollisiin aistitoimintoihin perustuvaksi. Juha Varton $(2003,13)$ mukaan sana estetiikka tulee Kreikasta. Aisthesis tarkoittaa aistisuutta, jolla viitataan ihmisen konkreettiseen suhteeseen maailman kanssa. Esteettinen kokemus merkitsee aistinvaraisen tietoisuuden syventymistä, jonka voi aiheuttaa mikä tahansa aistimus

12. Varton (1994, 87-90; 2003, 64-67) mukaan kokonaisen maailmasuhteen vastakohta on ohentunut maailmasuhde, jossa merkitykset määrää ihmisen ruumiiton mieli, henki. Tällaista välineellistä maailmasuhdetta pidetään pääistyneenä, koska sen sisällön ja muodon ratkaisee ihmisen pää, siis mielen kuvittelukyky, jonka avulla ihminen valitsee kokemastaan haluamansa ja jättää pois sen mitä ei halua. Näin syntyvässä maailmassa vallitsee ihmisen mittakaava, ja ratkaisevaksi nousevat ideat, toiveet, kuvitelmat, yleensäkin ajatukset siitä kuinka pitäisi. Tällöin ihminen käyttää itseään ja ympäristöään välineinä, joiden olemassaolo on riippuvainen ihmisen kulloisistakin tarpeista ja käytännöistä. Näin ihminen tuottaa sitä, mitä jo on ja minkä hän jo tietää. Tällaisessa perinteessä tekeminen ei paljasta maailmaa, luontoa tai ihmistä, vaan pikemminkin peittää näitä yhä mutkikkaampien käsitysten ja kuvitelmien alle

13. Kuvataiteellinen työskentelyni vertautuu osuvasti fenomenologiaan, joka perustuu yksikön ensimmäisen persoonan - minän - näkökulmaan ja 
tarkastelee muuttumattoman olevan sijaan ilmenevää (Husserl 1995, 41). Taiteeseen fenomenologian yhdistää kaiken kokemisen alkuperän tavoittelu, jolloin tietoisuus ja sen kohde eivät ole vastakkaisia toisilleen, vaan ne kuuluvat yhteen. Tämä alkuperäinen kokemus voidaan ymmärtää käsitteellistä ajattelua edeltäväksi aistimiseksi ja tuntemiseksi. (Haapala \& Lehtinen 2000, XXXI-XXXII.)

\section{Lähteet}

Von Bonsdorff, Pauline (2000). Mikel Dufrennen teoria tunteiden apriorisuudesta: Esteettinen kokemus maailman tuntemisena. Teoksessa Haapala, Arto \& Lehtinen, Markku (toim.) Elämys, taide ja totuus. Kirjoituksia fenomenologisesta estetiikasta, 183-204.

Cragg, Tony (1999a). Kuvanveisto - materiaalin laajennukset. Suom. Tytti Suojanen. Teoksessa Valorinta, Riitta (toim.) Tony Cragg. Teoksia 1987-1999. Tampere: Sara Hildénin taidemuseon julkaisuja 65, 104-108.

Cragg, Tony (1999b). Wirbelsäule - Nivelpyväs. Suom. Tytti Suojanen. Teoksessa Valorinta, Riitta (toim.). 1999. Tony Cragg. Teoksia 1987-1999. Tampere: Sara Hildénin taidemuseon julkaisuja 65, 109-112.

Efland, Arthur D., Freedman, Kerry \& Stuhr, Patricia (1998). Postmoderni taidekasvatus. Eräs lähestymistapa opetussuunnitemaan. Helsinki: Taideteollinen korkeakoulu, Taidekasvatuksen osasto.

Eteläpelto, Anneli \& Rausku-Puttonen, H. (2002). Projektioppimisen haasteet ja mahdollisuudet. Teoksessa: Eteläpelto, Anneli \& Tynjälä, Päivi (toim.) Oppiminen ja asiantuntijuus. Helsinki: WSOY, 181-205.

Haapala, Arto \& Lehtinen, Markku (2000). Johdanto. Katsaus fenomenologian syntyyn ja kehitykseen Saksassa ja Ranskassa. Teoksessa Haapala, Arto \& Lehtinen, Markku (toim.). Elämys, taide ja totuus. Kirjoituksia fenomenologisesta estetiikasta. Helsinki: Yliopistopaino, IX-LXII.

Hannula, Mika (1998). Ei lisää kitarasankareita, kiitos. Teoksessa Jaukkuri, Maaretta, Nyberg, Patrik \& Hannula, Mika. Nykytaiteen tulkintaa. Helsinki: Ateneum, Valtion taidemuseon museojulkaisu, 77-146.

Hannula, Mika, Suoranta, Juha \& Vadén, Tere.
(2003). Otsikko uusiksi. Taiteellisen tutkimuksen suuntaviivat. Tampere: niin \& näin -lehden filosofinen julkaisusarja 23-45.

Heidegger, Martin (1995). Taideteoksen alkuperä. Suom. Hannu Sivenius. Helsinki: Kustannusosakeyhtiö Taide Oy. Aluperäisteos: Der Ursprung des Kunstwerkes. 1935/1936. Frankfurt am Main: Vittorio Klostermann.

Hetemäki, Ilari (toim.) (1999). Filosofian sanakirja. Helsinki: WSOY.

Husserl, Edmund (1995). Fenomenologian idea - viisi luentoa. Suom. Juha Himanka, Janita Hämäläinen \& Hannu Sivenius. Helsinki: Loki-Kirjat Oy. Alkuperäisjulkaisu: Die Idee der Phänomenologie.

Iitiä, Inkamaija (2003). Osmo Rauhalan tieteenkritiikistä ja taiteen etiikasta. Teoksessa Iitiä, Inkamaija (toim.). Osmo Rauhala. Luonnon aika. Helsinki: Otava, 123-141.

Ingarden, Roman (2000). Fenomenologinen estetiikka. Suom. Hannu Koskenranta. Teoksessa Haapala, Arto \& Lehtinen, Markku (toim.) Elämys, taide ja totuus. Kirjoituksia fenomenologisesta estetiikasta. Helsinki: Yliopistopaino, 1-26.

Jaukkuri, Maaretta (1998). Edestakaista liikettä taiteen ja arjen välillä Teoksessa Jaukkuri, Maaretta, Nyberg, Patrik \& Hannula, Mika (toim.). Nykytaiteen tulkintaa. Helsinki: Ateneum, Valtion taidemuseon museojulkaisu, 146.

Lyytinen, Heikki, Eklund, K. \& Laakso, M-L. (2000). Varhainen kognitio, temperamentti ja vuorovaikutus. Teoksessa: Lyytinen, Paula, Korkiakangas, Mikko \& Lyytinen, Heikki (toim.) Näkökulmia kehityspsykologiaan. Kehitys kontekstissaan. Helsinki: WSOY, 4065.

Klemola, Timo (2005). Taidon filosofia - Filosofin taito. 2. painos. Tampere: Tampereen Yliopistopaino Oy.

Kupiainen, Reijo (1997). Heideggerin ja Nietzschen taidekäsitysten jäljillä. Helsinki: Gaudeamus.

Luoto, Miika (2000). Taide ja totuus Heideggerin ajattelussa. Teoksessa Haapala, Arto \& Lehtinen, Markku (toim.) Elämys, taide ja totuus. Kirjoituksia fenomenologisesta estetiikasta. Helsinki: Yliopistopaino, 93-120.

Merleau-Ponty, Maurice (1962). Phenomenology 
of Perception. Kääntäjä Colin Smith. Lontoo. Alkuperäisjulkaisu: Phénoménologie de la perception. 1945. Pariisi.

Merleau-Ponty, Maurice (1993). Cézannen epäily. Suom. Irmeli Hautamäki. Taide (33) 1/1993, 35-44. Alkuperäisjulkaisu: Le doute de Cézanne. Teoksessa Collection Pensés, Maurice Merleau-Ponty, Sens et non-sens. 1945/1966. Pariisi: Les Editions Nagel.

Merleau-Ponty, Maurice (2006). Silmä ja mieli. 2. painos. Suom. Kimmo Pasanen. Helsinki: Kustannusosakeyhtiö Taide. Alkuperäisjulkaisu: L’Eil et l'Esprit. 1964. Pariisi: Editions Gallimard.

Morris, Robert (1993). Continuous Project Altered Daily: The Writings of Robert Morris. Cambridge, Massachusetts: The MIT Press.

Nordin, Svante (1999). Filosofian historia. Suom. Jukka Heiskanen. Oulu: Kustannusosakeyhtiö Pohjoinen. Alkuperäisjulkaisu: Filosofins historia. Student litteratur. 1995. Lund.

Parviainen, Jaana (2000). Kehollinen tieto ja taito. Teoksessa Ajatus 57 - Suomen filosofisen yhdistyksen vuosikirja 2000, 147-166. Helsinki: Suomen filosofinen yhdistys.

Parviainen, Jaana (2006). Meduusan liike. Mobiiliajan tiedonmuodostuksen filosofiaa. Helsinki: Gaudeamus.

Pasanen, Kimmo (2005). Taiteellisen ajattelun ulottuvuuksia. Taide, 45 (3), 28-31.

Pasanen, Kimmo (2006). Maurice Merleau-Ponty: Aistivan minän filosofi. Suomentajan jälkisanat teoksessa Merleau-Ponty, Maurice. Silmä ja mieli. 2. painos. Helsinki: Kustannusosakeyhtiö Taide, 74-96.

Pitkänen-Walter, Tarja (2001). Kuvan tunto-oppia tavailemassa. Teoksessa: Hannula, Mika \& Kiljunen, Satu (toim.). Taiteellinen tutkimus.
Helsinki: Kuvataideakatemia, 125-139.

Pullinen, Jouko (2003). Mestarin käden jäljillä. Kuvallinen dialogi filosofisen hermeneutiikan näkökulmasta. Helsinki: Taideteollisen korkeakoulun julkaisu A 40.

Rauste-von Wright, Maijaliisa, von Wright, Johan \& Soini, Tiina (2003). Oppiminen ja koulutus. 9. uudistettu painos. Helsinki: WSOY.

Sakari, Marja (2000). Käsitetaiteen etiikkaa. Suomalaisen käsitetaiteen postmodernia ja fenomenologista tulkintaa. Helsinki: Valtion taidemuseon tieteellinen sarja, Dimensio 4.

Siukonen, Jyrki (2002). Tutkiva taiteilija. Kysymyksiä kuvataiteen ja tutkimuksen avoliitosta. Helsinki: Kustannusosakeyhtiö Taide ja Lahden Ammattikorkeakoulu/Taideinstituutti.

Tynjälä, Päivi (1999). Oppiminen tiedon rakentamisena. Konstruktivistisen oppimiskäsityksen perusteita. Helsinki: Kirjayhtymä Oy.

Uusikylä, Kari \& Atjonen, Päivi (2000). Didaktiikan perusteet. Helsinki: WSOY.

Vaherva, Tapio (2002). Henkilöstökoulutuksen rajat ja mahdollisuudet. Teoksessa: Eteläpelto, Anneli. \& Tynjälä, Päivi. (toim.) Oppiminen ja asiantuntijuus. Helsinki: WSOY, 83-101.

Varto, Juha (1990). Liikunnan etiikka. Hyvä ja paha, oikea ja väärä kehon ratkaisemina. Teoksessa Varto, Juha (toim.). Liikunnan filosofia. Eri tarkastelukulmia. Tampere: Filosofisia tutkimuksia Tampereen yliopistosta XIII, TALFIT liikunnan filosofian tutkimus, 115-131.

Varto, Juha (1994). Filosofian taito 1. Helsinki: Kirjayhtymä Oy.

Varto, Juha (2003). Kauneuden taito. 3. painos. Tampere: Tampereen yliopistopaino.

Vuorinen, Jyri (1993). Estetiikan klassikoita. Helsinki: Suomalaisen kirjallisuuden seura. 